\title{
APPAREL SHOPPING BEHAVIOUR - PART 2: CONCEPTUAL THEORETICAL MODEL, MARKET SEGMENTS, PROFILES AND IMPLICATIONS
}

\author{
R DU PREEZ \\ Department of Industrial Psychology \\ University of Stellenbosch \\ EM VISSER \\ Department of Consumer Science: Food, Clothing, Housing \\ University of Stellenbosch
}

\begin{abstract}
This article is based on the conceptual theoretical model developed in Part 1 of this series of articles. The objective of this research is to identify female apparel consumer market segments on the basis of differentiating lifestyles, shopping orientation, cultural consciousness, store patronage and demographics. These profiles are discussed in full and the implications thereof for retailers, marketers and researchers are highlighted. A new conceptual model is proposed and recommendations are made for further research.
\end{abstract}

\section{OPSOMMING}

Hierdie artikel word gebaseer op die konseptuele teoretiese model wat reeds in Deel 1 van hierdie artikelreeks ontwikkel is. Die doel van hierdie navorsing is om marksegmente van vroue klere-kopers te identifiseer na aanleiding van hulle lewenstyle, kooporiëntasie, kulturele bewustheid, winkelvoorkeurgedrag en demografie. Hierdie profiele word volledig beskryf en die implikasies van die verskillende profiele vir kleinhandelaars, bemarkers en navorsers word uitgelig. 'n Nuwe konseptuele model word voorgestel en aanbevelings vir verdere navorsing word gemaak.

Female apparel shopping behaviour in a multicultural consumer society is a complex phenomenon. The apparel industry in South Africa is large and capital and people intensive. This warrants research to gain knowledge about the end user of the products in order to sustain growth and prosperity. With the introduction of the African Growth and Opportunity Act (AGOA) in October 2000, a window of opportunity was opened that cannot be negated (Textile Statistics \& Economic Review $1999 / 2000,2000)$. No research could be identified during this study that profiled female apparel shoppers in South Africa. In addition, very little research included respondents from a variety of South African ethnic and cultural environments.

Researchers and retailers cannot afford to ignore socioeconomic changes. Black people form the majority in South Africa and have a huge amount of spending power, especially in the aspirational market described by Allemann (2000). Shim and Kotsiopulos (1993) state that multicultural studies could be a source of interesting patterns and results regarding apparel consumer behaviour, as consumers with different cultural backgrounds differ in their respective apparel shopping behaviour. Women today are economically more active, marry later in life, have fewer children, have more decision-making power and are becoming a lucrative market segment (Bartos, 1994; Bruce \& Parkinson-Hill, 1999; Cassill, 1990; Du Plessis \& Rousseau, 1999; Erasmus \& van Zyl, 1994; Nelson, 1994; Schaninger, Nelson \& Danko, 1993).

In an attempt to understand female apparel shopping behaviour in a multicultural consumer society, part one of this two-part series focussed on the development of a conceptual theoretical model that provides a macro-perspective of the variables influencing apparel shopping behaviour. In Part 2, the focus will be on an empirical application of a selection of these variables, the market segments that were derived therefrom, as well as on the implications for marketers, retailers and academia. The results will culminate in the development of a theoretical model of selected variables influencing female apparel shopping behaviour in a multicultural consumer society (refer to Figure 2).

Requests for copies should be addressed to: $R$ du Preez, Department of Industrial Psychology, University of Stellenbosch, Private Bag X1, Matieland, 7602
The research problem of this exploratory study was twofold: What are the variables influencing female apparel shopping behaviour within a multicultural consumer society and can distinct clusters of female apparel shoppers be identified? The first part of this research problem was reported in Part 1 of this series of articles. The objectives of the second component, reported in this paper, are to:

1. investigate whether distinct clusters of female apparel shoppers exist according to lifestyle, shopping orientation, cultural consciousness, patronage behaviour and demographics

2. determine which of these variables contribute to differences between clusters

3. determine between which clusters these differences occur

4. profile different clusters of female apparel shoppers that share the same characteristics according to the differentiation variables

5. examine and formulate the implications of these different cluster profiles for apparel marketers and retailers in terms of the marketing mix and target markets

6. formulate the implications for marketers and retailers of apparel, as well as for researchers, educators and students

7. make recommendations for future research

8. develop a new conceptual theoretical model based on the results of the empirical study.

\section{LITERATURE REVIEW}

In the literature review presented in Part 1 of this series, various models were discussed and the synthesis of the Conceptual theoretical model: a macro-perspective of variables influencing apparel shopping behaviour was described. The following section will briefly focus on those variables selected for the purposes of the empirical study.

Two market-dominated variables were selected for inclusion in the study, viz. the apparel product and the place of distribution. The combination of fashion and seasonal changes make the apparel business one of the most changeintensive businesses in the world. Sproles (1981) emphasised that apparel and fashion apparel is under-researched in 
comparison to other major consumer products. In South Africa, the emerging black middle class is status conscious and tends to reflect status in the use of products. Apparel is regarded as the third highest status item $(8.2 \%)$, after cars $(65.3 \%)$ and cellphones (10.2\%), and therefore the apparel worn is seen as a reflection of an individual's status in society (The status society, 1999, p. 12). Consumers choose retail outlets according to their shopping orientations. The challenge for manufacturers is to distribute their merchandise to the correct stores so that consumers in the target market will patronise those stores.

The second main component of the conceptual theoretical framework of selected variables influencing female apparel shopping behaviour is the market and consumer interaction component. Patronage behaviour and shopping orientation, the two variables classified here, are mutually influenced by market- and consumer-dominated variables.

Sproles and Burns (1994) emphasise that apparel purchases are different from the purchase of home appliances, as most consumers do not formally gather product information prior to the purchase, but rather make most of their decisions in-store. The choice of a store to patronise is therefore of great importance, as apparel consumers will often gather information, evaluate alternatives and make decisions at the point of purchase. Shopping orientation is a complex and multidimensional concept and there is little consensus with regard to the underlying structure or dimensionality of apparel shopping orientation (Hawkins, Best \& Coney, 1998; Shim \& Bickle, 1994; Shim \& Mahoney, 1992). Shopping orientations are dependent on the product of choice and the retail store type (Solomon, 1999). Darden and Howell (1987) state that this complexity could be the reason why so much of the variation in shopping orientation still remains unexplained. To address this problem, Visser and Du Preez (2001) suggest a new classification of shopping orientations comprising the following categories: enjoyment, interests and activities, confidence, opinion leadership, fashion orientation, shopping convenience, time, finance, brand consciousness and patronage.

The third component is consumer-dominated variables, including demographics and socio-cultural variables. South Africa has a diverse population with varying levels of education and income. South African cultural values have changed over the last ten years. As South Africa is becoming more globally orientated and competitive, more marketing and retailing opportunities will emerge. It is within this scenario that the South African apparel consumer should be studied. Lifestyle and psychographic analyses address the unique patterns of living that influence and reflect consumer behaviour (Hawkins et al., 1998; Loudon \& Della Bitta, 1993).

Consumer goods, and specifically apparel and dress, have the ability to carry and communicate cultural meaning (Chung, 1998; Damhorst, Miller \& Michelman, 1999; Kaiser, 1997; O'neal, 1998; Trollip, 1992a \& 1992b). Shaw and Clarke (1998) support this and state that postmodern theory suggests that individuals consume the symbolic meaning of products, rather than just the product itself.

\section{METHOD}

The store-intercept method as a variation of the mall-intercept interviewing method of data collection was used. In-store research is very popular in the Consumer Sciences, as it holds a number of advantages over other methods. The biggest advantages are the realism of the environment, the immediacy of the data collection and the reduction of artificial influences (Bush \& Hair, 1985; Dillon, Madden \& Firtle, 1994; Hester, 1989; Loudon \& Della Bitta, 1993).

\section{Sample population}

The sample population included female consumers between the ages of 18 and 55, browsing for or buying clothes for themselves and/or family members in selected discount, chain speciality and department stores. Shopping is not equivalent to buying, as many shoppers do not buy a specific item but rather browse. Females were chosen because they are primarily responsible for apparel purchases and are the main market segment targeted by various apparel retail outlets (Bruce \& Parkinson-Hill, 1999; Darden \& Dorsch, 1990; Erasmus \& Van Zyl, 1994).

\section{Sample selection}

To make provision for the major limitations of store-intercept interviewing, the sample selection process was done rigorously. Three types of stores were included, namely discount, chain speciality and departmental stores. The age group was specified as 18-55. Black, coloured and white respondents were included in equal numbers by applying a quota sampling method. The Indian population was excluded from this stratified quota sample, as they represent a very small percentage of the population in the selected geographical areas (Western Cape and North West Province) (Statistics SA, 2000). Care was taken not to "self-select" the sample according to the time of day and the day of the week that consumers shop by including morning, lunchtime and afternoon shoppers over six days of the week and over a two-week period. Data were gathered in the provinces by trained fieldworkers (Du Preez, 2001).

\section{Questionnaire}

A questionnaire comprising five sections was developed using published literature, as well as by compiling questions with the objectives of the study in mind. Some existing items were used and adapted for South African circumstances where necessary. All statements, except demographics, were rated on a five-point Likert-type scale and was pilot tested. The questionnaire showed acceptable reliability (Refer to Table 1).

\section{TABLE 1}

\section{QUESTIONNAIRE DESIGN}

\begin{tabular}{lcl}
\hline Section & $\begin{array}{l}\text { Number } \\
\text { of items }\end{array}$ & $\begin{array}{l}\text { Sources for the } \\
\text { development of items }\end{array}$ \\
\hline Section A: Patronage behaviour & 13 & Shim \& Kotsiopulos (1992a) \\
Section B: Lifestyle $(\alpha=0.82)$ & 30 & $\begin{array}{l}\text { Booher (1996); Cassill \& Drake } \\
(1987) ; \text { Fox (1989); Visser \& Du }\end{array}$ \\
& & $\begin{array}{l}\text { Preez (1996, 1998) } \\
\text { Section C: Cultural }\end{array}$ \\
consciousness $(\alpha=0.58)$ & 12 & $\begin{array}{l}\text { Aaker \& Maheswaran (1997); } \\
\text { Hofstede (1991); Kotzé (1993); } \\
\text { Rieger \& Blignault (1996); } \\
\text { Triandis, Bontempo, Villareal, } \\
\text { Asai \& Lucca (1988); Triandis, } \\
\text { McCusker \& Hui (1990) }\end{array}$ \\
$\begin{array}{lcl}\text { Section D: Shopping orientation } \\
(\alpha=0.75)\end{array}$ & 22 & $\begin{array}{l}\text { Shim \& Kotsiopulos (1992 a } \\
\text { \& b, 1993); Visser \& Du Preez } \\
(1996,1998)\end{array}$ \\
Section E: Demographics & & \\
\hline
\end{tabular}

Data capturing was done by means of the Formic system (a computerised scanning and data-capturing program). The statistical analysis was performed with the SPSS 8.0 statistical package (1998).

\section{RESULTS}

\section{Sample profile}

A near-equal representation of black ( $\mathrm{n}=246$ or $33.84 \%)$, white $(\mathrm{n}=244$ or $33.56 \%)$ and coloured $(\mathrm{n}=237$ or $32.60 \%)$ respondents was obtained through quota sampling procedures. 
Afrikaans was the dominant language (53.33\%), followed by English (10.51\%) and Xhosa (10.10\%). The near-equal age distribution of the respondents is an advantage, as it reduces the possibility that age, as a single variable, had a significant indirect impact on cluster formation. The sample had a relatively high educational level, with $71 \%$ having attained a Grade 12 qualification or higher. This high educational level is, however, not a true reflection of the educational level of the South African population (Du Plessis \& Rousseau, 1999) and is probably due to the selected geographical regions (in the proximity of universities). The lower middle income group $(28 \%=\mathrm{R} 1001-$ $\mathrm{R} 3000$ and $18 \%=\mathrm{R} 3001-\mathrm{R} 7000)$ was the largest income bracket as $46 \%$ of the respondents fell into this bracket. Nineteen percent of the respondents were in the upper middle income group and the highest income group (R10 001 and more) showed a $17 \%$ representation.

\section{Clusters of female apparel shoppers}

The present research project investigated whether there are distinct clusters of female apparel shoppers according to the variables lifestyle, shopping orientation, cultural consciousness and patronage behaviour. The Ward clustering method and the Squared Euclidean distance method were applied for the measurement of similarity. Clustering of cases (733) was performed, excluding 66 missing cases. Three lifestyle components, three shopping orientation components, individualism and collectivism composite scores and the 11 patronage scores were used as clustering variables. Three clusters were extracted. Cluster one was the largest with $n=363$ (49.5\%), followed by cluster two with $\mathrm{n}=205(28 \%)$ and cluster three with $\mathrm{n}=165(22.5 \%)$. From the cluster analysis it can be deduced that female apparel consumers are not a single homogeneous market. This market could be successfully segmented, resulting in different cluster profiles with variations in lifestyle, shopping orientation, cultural consciousness and patronage behaviour.

\section{One-way MANOVA}

It was further necessary to establish if the dependent variables (patronage behaviour, lifestyle, cultural consciousness and shopping orientation) differ as a whole across the cluster groups (independent variable). The results are depicted in Table 2 .

TABLE 2

ONE-WAY MANOVA

\begin{tabular}{lcccccc}
\hline Effect & Value & F & $\begin{array}{c}\text { Hypothesis } \\
\text { Df }\end{array}$ & Error df & Sig. & $\begin{array}{c}\text { Eta } \\
\text { Squared }\end{array}$ \\
\hline 3 Clusters & & & & & & \\
Wilks Lambda & .002 & 278.501 & 57.000 & 2123.782 & 0.000 & .880 \\
\hline
\end{tabular}

The results indicate a statistically significant difference at the $1 \%$ level $(p<0.01)$ between the three cluster groups based on the dependent variables as a whole. Eighty-eight percent of the variance in the dependent variables as a whole can be attributed to cluster membership (independent variable). It can thus be concluded that three clusters exist and they differ with regard to the dependent variables as a whole.

\section{One-way ANOVA}

The one-way ANOVA was applied to establish which of the dependent variables varied significantly among the different cluster groups. Only these variables can confidently be used in the profiling of the different cluster groups. All the dependent variables differed at a statistically significant level $(p=0.000$; $p=0.016$; $p=0.036$ ) across the three cluster groups. The size of the differences varies between the clusters ( $F$ value), but is still significant. The three cluster profiles according to mean scores are presented graphically in Figure 1.

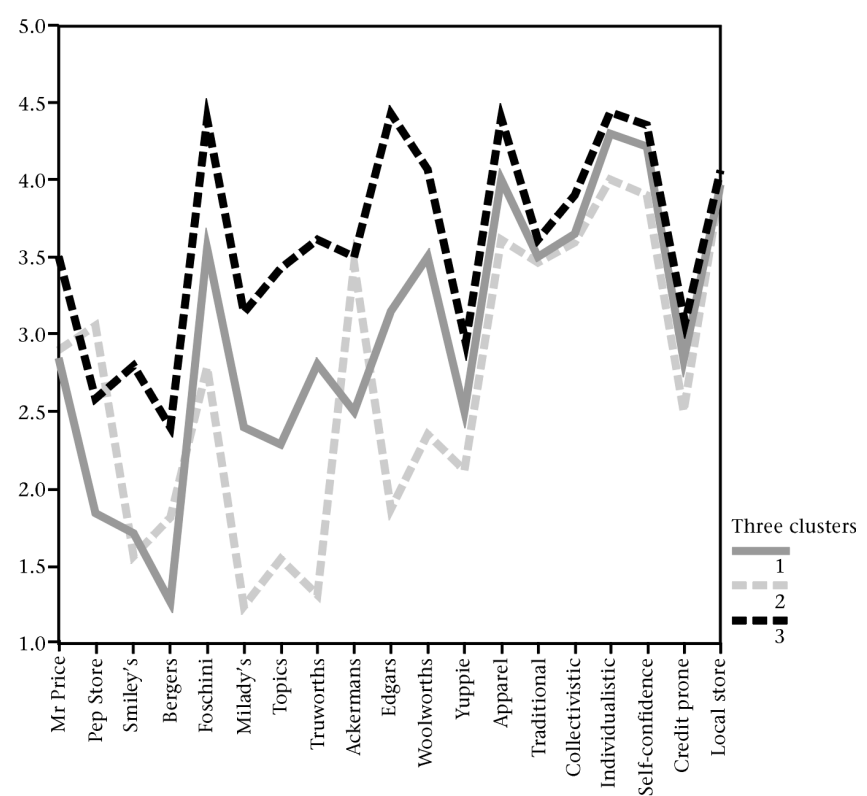

Figure 1: Cluster profiles according to mean scores

\section{One-way ANOVA F statistics}

All the patronage variables differ significantly $(p<0,05)$ across cluster membership. Clusters differed most with regard to the buying of apparel at Edgars and the least with regard to Mr Price apparel purchases. Pricing structure, apparel style and merchandising could contribute to the results. Other possible explanations include the relationship between lifestyle and apparel evaluative criteria (Cassill \& Drake, 1987), lifestyle influences on patronage behaviour (Booher, 1996), lifestyle and importance of store attributes (Huddlestone, Ford \& Mahoney, 1990), shopping orientation and patronage behaviour (Engel, Blackwell \& Miniard, 1995; Darden \& Howell, 1987; Shim \& Kotsiopulos, 1992a; Shim \& Kotsiopulos, 1992b) and differences in the demographic and psychographic profile of a speciality store's customers and non-customers (Thorpe \& Avery, 1983-1984).

The lifestyle of the cluster groups differed mostly with regard to the principle component, namely yuppie lifestyle, followed by the apparel-orientated lifestyle and the traditional lifestyle principle components. Educational level, employment status, income, age and expenditure all impact on lifestyle (ACNielsen, 1999; Allemann, 2000; Ives, 1999; SAARF LSM, 1999; Schiffman \& Kanuk, 2000; Values and Lifestyles, 2001). The largest differences exist between the clusters regarding educational level, employment status, household income and apparel expenditure.

Regarding cultural consciousness, the cluster groups differed mostly in terms of individualism, followed by collectivism. Although the differences are small, the result is still statistically significant $(p<0.01)$. The results of the cultural consciousness $F$ statistic are not entirely surprising, as cultural consciousness was measured in an environment that is not characterised by deeply entrenched traditional cultural values.

The results of the shopping orientation F statistic indicate that the principle component, namely credit prone, brand conscious and fashion-innovative, differed the most between the groups, although the difference is still relatively small. The second largest differentiating principle component was shopping self-confidence and enjoyment, followed by the local store patronage component. Apparel consumers are usually clear with regard to whether they see themselves as brand-conscious or not and whether they are fashion innovators or not (Huddleston, Ford \& Bickle, 1993).

\section{Bonferroni results}

The post hoc test, Bonferroni multiple comparisons, was applied. The results indicate that the cluster groups vary statistically 
significantly across 14 of the variables between all the clusters. Six variables did not significantly differentiate between all possible cluster groupings. The results from the Bonferroni analysis can assist in the profiling of cluster groupings. Those variables that vary statistically significantly across all the cluster groupings should be given a greater value than those that do not differ across all cluster groups.

\section{Cluster profiles}

Cluster profiles of female apparel shoppers were developed. Variables that differed statistically significantly can be used with confidence in the typology of the clusters. The following labels were ascribed to the three clusters according to the profile description: Cluster 1: Actualisers ( $\mathrm{n}=363,49.5 \%)$; Cluster 2: Strugglers ( $\mathrm{n}=205,28 \%)$; and Cluster 3: Aspirationals $(\mathrm{n}=165,22.5 \%)$. Table 3 gives a summary of the most prominent characteristics of the respective cluster profiles. Only key words were used to give an overview of the cluster typologies. The profiles are supported by previously published international and South African literature. Similarities exist between the profiles reported by the VALS 2 classification system (Values and Lifestyles, 2001), the Sociomonitor (ACNielsen, 1999) and the profiles of Fournier, Antes and Beaumier (1992), Allemann (2000) and Shim and Kotsiopulos (1992b, 1993).

\section{A new theoretical model}

The proposed new theoretical model incorporates the results of the empirical study, as well as the literature reported in Part 1 of this series of articles. Firstly, the model provides three categories in order to group the variables that impact on female apparel shopping behaviour and, secondly, it provides information regarding the multi-dimensionality of the influencing constructs. Thirdly, it portrays three clusters of female apparel shoppers in a multicultural consumer society. Lastly, it can serve as a basis for future research, as the other variables mentioned in the Conceptual theoretical model: a macro-perspective of variables influencing apparel shopping behaviour. (refer to Figure 1 in Part 1) should also be studied within the South African female apparel consumer market and incorporated in the model.

\section{IMPLICATIONS FOR MARKETERS AND RETAILERS}

In the consumer-driven $21^{\text {st }}$ century, sophisticated consumers will decide how they intend to spend their money, be more knowledgeable regarding products and services, and be accustomed to a huge variety of choices. Marketers and retailers who use information regarding female apparel consumers will have an advantage in the competitive marketplace.

\section{Implications for marketers of apparel}

The macro-perspective model provides marketers of apparel with a holistic view of variables influencing female apparel shopping. The micro-perspective gives more detailed information on selected variables. Female apparel consumers differ with regard to their demographic characteristics, store patronage, lifestyle, culture and shopping orientations. Differentiated marketing strategies are therefore necessary for the three consumer groups identified in this study. This impacts on media preferences (for example the use of websites), message strategies, as well as on the layout and execution of advertisements aimed at female apparel shoppers.

\section{Implications for retailers of apparel}

The cluster profiles can assist apparel retailers in the identification of target markets in order to establish a scientifically-based and appropriate marketing strategy and mix. Consequently, retailers could successfully meet the apparel needs of the target market by selecting the most suitable type of product, pricing structures, promotional campaign and mix, and distribution channels. The choice of apparel items will be influenced by variables such as demographics, stage in the family life cycle, income, employment orientation, shopping orientation and lifestyle. Promotional efforts by the retailer should focus on these variables in order to reach the target market, for example if the target market "fits" the Actualisers and/or the Aspirationals profiles, in-store promotional efforts should centre around making the shopping experience fun, entertaining and enjoyable.

Implications for researchers, educators and students

Educators in the field of Clothing can benefit from the development of the models in various ways. They provide a

TABle 3

SUMMARY PROFILE OF CLUSTER GROUPS

\begin{tabular}{|c|c|c|c|}
\hline VARIABLE & $\begin{array}{l}\text { CLUSTER } 1: 49.5 \% \\
\text { ACTUALISERS }\end{array}$ & $\begin{array}{l}\text { CLUSTER 2: } 28 \% \\
\text { STRUGGLERS }\end{array}$ & $\begin{array}{l}\text { CLUSTER 3: } 22.5 \% \\
\text { ASPIRATIONALS }\end{array}$ \\
\hline Demographics & $\begin{array}{l}\text { - White and coloured majority } \\
\text { - African minority } \\
\text { - } \quad 18-25 ; 35 \text { plus } \\
\text { - Majority married; later FLC stages } \\
\text { - } \text { Highest educational levels } \\
\text { - } \text { Highest total household income } \\
\text { - } \\
\text { Multiple vehicle ownership }\end{array}$ & $\begin{array}{l}\text { - } \quad \text { African and coloured majority } \\
\text { - } \quad \text { Afrikaans, Xhosa and Twana } \\
\text { - } 26-34 ; 40 \text { plus } \\
\text { - } \text { Married; parenthood FLC stage } \\
\text { - Lowest apparel expenditure } \\
\text { - } \text { Lowest educational levels } \\
\text { - } \text { Clerck, middle management, } \\
\text { - } \text { domestic workers, unemployed } \\
\text { Public transport and taxis }\end{array}$ & $\begin{array}{l}\text { - } \text { African majority } \\
\text { minority } \\
\text { - } \text { Afrikaans, Xhosa and Twana } \\
\text { - } \text { Youngest; majority unmarried } \\
\text { - Students, professional, clercks, } \\
\text { - } \text { middle management } \\
\text { - } \text { incomes educational levels, high } \\
\text { - Highest apparel expenditure } \\
\text { - Own and public transport }\end{array}$ \\
\hline Store patronage & $\begin{array}{l}\text { - Departmental and chain speciality } \\
\text { - Woolworths, Foschini, Edgars }\end{array}$ & $\begin{array}{l}\text { - Departmental and discount } \\
\text { - Ackermans, Pep Stores, Mr Price }\end{array}$ & $\begin{array}{l}\text { - Departmental and chain speciality } \\
\text { - Edgars, Foschini, Woolworths }\end{array}$ \\
\hline Lifestyle & $\begin{array}{l}\text { - Socially integrated: friends, dinners } \\
\text { - } \quad \text { Stylish dresscode } \\
\text { - } \quad \text { Radio and magazines }\end{array}$ & $\begin{array}{l}\text { - "Simple at home"; cooking and } \\
\text { baking; little outside activity } \\
\text { - Church and family } \\
\text { - Radio }\end{array}$ & $\begin{array}{l}\text { - Apparel-orientated lifestyle } \\
\text { - } \text { Active shoppers; window shopping } \\
\text { - } \text { High media usage - all types }\end{array}$ \\
\hline Cultural consciousness & - More individualistic & - More individualistic & - Individualistic and collectivistic \\
\hline Shopping orientation & $\begin{array}{l}\text { - } \quad \text { Confident apparel shoppers } \\
\text { - } \quad \text { Enjoy shopping experience } \\
\text { In-and out-shopping }\end{array}$ & $\begin{array}{l}\text { - Least brand consciousness } \\
\text { and credit-prone } \\
\text { - Little apparel opinion leadership } \\
\text { and fashion innovation } \\
\text { - Local store patronage }\end{array}$ & $\begin{array}{l}\text { - Very confident apparel shoppers } \\
\text { - Highest enjoyment levels } \\
\text { - Window shopping; brand- } \\
\text { - } \quad \text { Lonscious } \\
\text { - }\end{array}$ \\
\hline
\end{tabular}




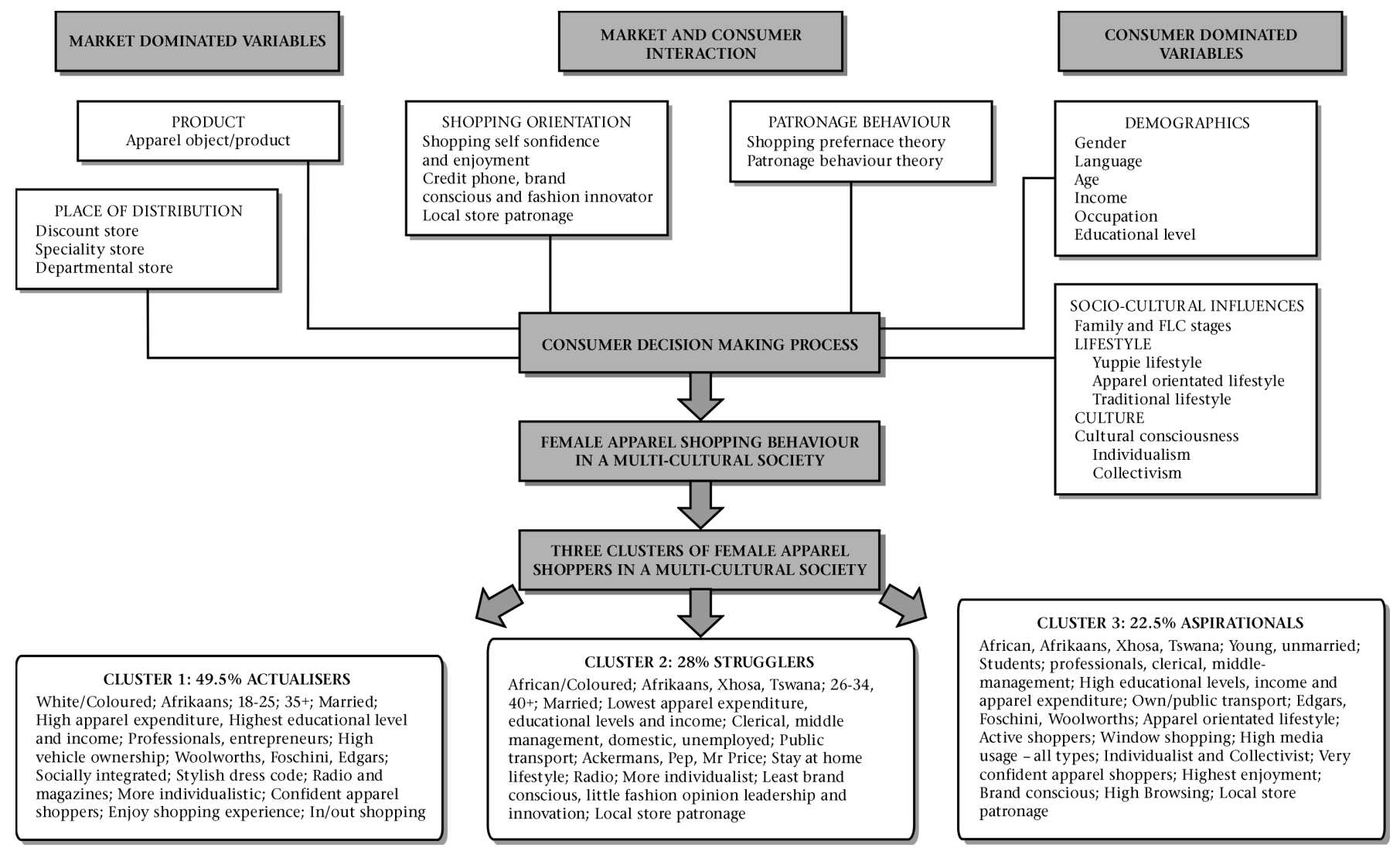

Figure 2: A theoretical model of selected variables influencing female apparel shopping behaviour in a multicultural consumer society

conceptual framework for the development of course curricula, especially in Consumer Behaviour. The study of consumer behaviour should include a holistic approach, as well as the social-psychological perspectives in clothing (cognitive, symbolic-interactionist and cultural perspectives). Most students find it difficult to visualise, understand and apply knowledge gained in one field of study, for example Clothing, to other disciplines, such as Consumer Behaviour. Consequently, students may benefit from their knowledge and understanding of the numerous variables that influence female apparel shopping behaviour in a multicultural consumer society. Grasping the meaning of the constructs and the multidimensionality thereof could be simplified by the interdisciplinary model and could encourage further interdisciplinary research. The models can thus facilitate new research initiatives and priorities.

\section{LIMITATIONS: PART 1 AND 2}

This study has many strengths, such as the size of the sample, the rigorous sampling methodology applied, the development of two models, as well as the profiles developed of three female apparel shopping groups. The fact that the questionnaire was available in Afrikaans and English only could influence the reliability of the responses. The models presented in this study investigated only selected variables, and the relationships between the variables were not examined. Consequently, the conceptual models do not have any predictive value.

\section{RECOMMENDATIONS FOR FUTURE RESEARCH}

Future research efforts could focus on the other variables that were presented in the macro-perspective model (refer to Figure 1 in Part 1). This can assist in building a more comprehensive, inclusive model of variables impacting on female apparel shopping behaviour. Investigating the relationships between the variables could increase the predictive value of the various conceptual models. The study could be replicated in the Generation $\mathrm{X}$ and $\mathrm{Y}$ markets, as these segments are extremely lucrative, with high expenditure on apparel. All stakeholders in the apparel industry could benefit from an understanding of the youth market's apparel shopping behaviour. The apparel shopping behaviour of male consumers could also be studied. Although this is a growing market segment, very little research in this regard has been done in South Africa.

\section{REFERENCES}

Aaker, J.L. \& Maheswaran, D. (1997). The effect of cultural orientation on persuasion. Journal of Consumer Research, 24, 315-328.

ACNielsen (1999). ACNielsen Sociomonitor 1999/2000 Johannesburg: ACNielsen.

Allemann, L. (2000). The African dream. Marketing Mix, 18 (5), 51-55.

Bartos, R. (1994). Point of view: Bartos responds to "The Bartos Model". Journal of Advertising Research, 34 (1), 54-56.

Booher, H.S. (1996). The influence of the Korean lifestyle on the purchase process of jeans. Unpublished Master's thesis, North Carolina State University, North Carolina.

Bruce, M. \& Parkinson-Hill, J. (1999). New trends in fashion: streetwear clothing. Journal of Fashion Marketing and Management, 3 (3), 272-281.

Bush, A.J. \& Hair, J.F. (1985). An assessment of the mall intercept as a data collection method. Journal of Marketing Research, $22,158-167$

Cassill, N.L. \& Drake, M.F. (1987). Apparel selection criteria related to female consumers' lifestyle. Clothing and Textiles Research Journal, 6(1), 20-28.

Cassill, N.L. (1990). Employment orientation of women as a market segmentation variable for apparel. Clothing and Textiles Research Journal, 9 (1), 59-64.

Chung, Y.S. (1998). Culture and consumption expenditure patterns: comparison between Korean and United States 
households. Journal of Consumer Studies and Home Economics, 22 (1), 39-50.

Damhorst, M.L., Miller, K.A. \& Michelman, S.O. (1999). The meanings of dress. New York: Fairchild Publications.

Darden, W.R. \& Dorsch, M.J. (1990). An action strategy approach to examining shopping behaviour. Journal of Business Research, 21, 289-308.

Darden, W.R. \& Howell, R.D. (1987). Socialization effects of retail work experience on shopping orientations. Journal of the Academy of Marketing Science, 15 (3), 52-63.

Dillon, W.R., Madden, T.J. \& Firtle, N.H. (1994). Marketing research in a marketing environment. (3rd ed.). Illinois: Irwin.

$\mathrm{Du}$ Plessis, P.J. \& Rousseau, G.G. (1999). Buyer behavior. a multicultural approach. (2nd ed.) Halfway House: International Thompson Publishing.

Du Preez, R. (2001). Female apparel shopping behaviour within a multi-cultural consumer society: variables, market segments, profiles and implications. Unpublished doctoral thesis, University of Stellenbosch, Stellenbosch.

Engel, J.F., Blackwell, R.D. \& Miniard, P.W. (1995). Consumer behaviour. ( $8^{\text {th }}$ ed.). New York: The Dryden Press.

Erasmus, A. \& Van Zyl, I. (1994). Die veranderende roloriëntasie, beroepsbetrok-kenheid en verbruikersgedrag van die vrou (The changing role orientation, career involvement and consumer behaviour of females). Journal of Dietetics and Home Economics, 22 (2), 109-115.

Fournier, S., Antes, D. \& Beaumier, G. (1992). Nine consumption lifestyles. Advances in Consumer Research, 19, 329-337.

Fox, R. (1989). Die tipering van verbruikerslewenstyle (The typology of consumer lifestyles). Unpublished master's thesis. University of Stellenbosch, Stellenbosch.

Hawkins, D.I., Best, R.J. \& Coney, K.A. (1998). Consumer behavior: building marketing strategy. (7th ed.). New York: McGraw-Hill.

Hester, S.B. (1989). Does attitude predict purchase behaviour of apparel products? Journal of Consumer Studies and Home Economics, 13, 161-174.

Hofstede, G. (1991). Cultures and organizations. Sotfware of the mind. London: McGraw-Hill.

Huddleston, P., Ford, I. \& Bickle, M.C. (1993). Demographic and lifestyle characteristics as predictors of fashion opinion leadership among mature consumers. Clothing and Textiles Research Journal, 11 (4), 26-31.

Huddleston, P., Ford, I. \& Mahoney, M.Y. (1990). The relationship between importance of retail store attributes and lifestyle of mature female consumers. Journal of Consumer Studies and Home Economics, 14, 71-85.

Ives, V. (1999). Black magic. Is the black middle-class consumer out there? Marketing Mix, 17 (7), 26-32.

Kaiser, S.B. (1997). The social psychology of clothing: symbolic appearances in context. (3nd ed.). New York: Fairchild Publications.

Kotzé, J.C. (1993). In their shoes - understanding black South Africans through their experiences of life. Johannesburg: Juta.

Loudon, D.L. \& Della Bitta, A.J. (1993). Consumer behavior: concepts and applications. (4th ed.) New York: McGraw Hill.

Nelson, C. (1994). How to market to women: understanding and reaching today's most powerful consumer group. Detroit: Visible Ink.

O'neal, G.S. (1998). African American women's professional dress as expression of ethnicity. Journal of Family and Consumer Sciences, 90 (1), 28-33.

Rieger, H.S. \& Blignaut, C.J.H. (1996). Individualiteit, kollektiwiteit en lokus van beheer as mikroveranderlikes van diversiteit (Individuality, colletivity and locus of control as micro variables of diversity). Journal of Industrial Psychology, 22 (3), 35-42.

SAARF LSM (1999). All you need to know about living standard measures. Johannesburg: South African Research Foundation.

Schaninger, C.M., Nelson, M. \& Danko, W.D. (1993). An empirical evaluation of the Bartos model of wife's work involvement. Journal of Advertising Research, 33 (3), 49-63.

Schiffman, L.G. \& Kanuk, L.L. (2000). Consumer behavior. (7th ed.). New Jersey: Prentice Hall.

Shaw, D.S. \& Clarke, I. (1998). Culture, consumption and choice: towards a conceptual relationship. Journal of Consumer Studies and Home Economics, 22 (3), 163-168.

Shim, S. \& Bickle, M.C. (1994). Benefit segments of the female apparel market: psychographics, shopping orientations, and demographics. Clothing and Textiles Research Journal, 12 (2), $1-12$.

Shim, S. \& Kotsiopulos, A. (1992a). Patronage behavior of apparel shopping: part I. Shopping orientations, store attributes, information sources and personal characteristics. Clothing and Textiles Research Journal, 10 (2), 48-57.

Shim, S. \& Kotsiopulos, A. (1992b). Patronage behavior of apparel shopping: part II. Testing a patronage model of consumer behavior. Clothing and Textiles Research Journal, 10 (2), 58-64.

Shim, S. \& Kotsiopulos, A. (1993). A typology of apparel shopping orientation segments among female consumers. Clothing and Textiles Research Journal, 12 (1), 73-85.

Shim, S. \& Mahoney, M.Y. (1992). The elderly mail-order catalog user of fashion products: a profile of the heavy purchaser. Journal of Direct Marketing, 6 (1), 49-58.

Solomon, M.R. (1999). Consumer behavior. (4th ed.). New Jersey: Prentice Hall.

Sproles, G.B. \& Burns, L.D. (1994). Changing appearances: understanding dress in contemporary society. New York: Fairchild Publications.

Sproles, G.B. (1981). Perspectives of fashion. Minneapolis: Burgess. SPSS base 8.0 application guide (1998). Chicago: SPSS.

Statistics SA (2000). South African statistics 2000. Pretoria: Statistics South Africa.

Textile statistics and economic review 1999/2000. (2000). Johannesburg: SA Textile Federation.

The status society (1999). Marketing Mix, 17 (10), 12.

Thorpe, D.I. \& Avery, C.E. (1983-1984). A demographic and psychographic assessment of a specialty store's customers and non-customers. Clothing and Textiles Research Journal, 2 , $35-41$.

Triandis, H.C., Bontempo, R., Villareal, M.J., Asai, M. \& Lucca, N. (1988). Individualism and collectivism: cross-cultural perspectives on self-ingroup relationships. Journal of Personality and Social Psychology, 54 (2), 323-338.

Triandis, H.C., McCusker, C. \& Hui, C.H. (1990). Multimethod probes of individualism and collectivism. Journal of Personality and Social Psychology, 59 (5), 1006-1020.

Trollip, A-M. (1992a). Die rol en betekenis van kleding as uitdrukkingsvorm van kollektiewe gedrag tydens die akkulturasieproses: 'n etnologiese benadering (The role and meaning of clothing as means of expression of collective behaviour during the acculturation process: an ethnological approach). Journal of Dietetics and Home Economics, 20 (2), 64-68.

Trollip, A-M. (1992b). Die betekenis en rol van kleding as uitdrukkingsvorm van individuele gedrag: 'n kultureelsielkundige benadering (The role and meaning of clothing as means of expression of individual behaviour: a culturalpsychological approach). Journal of Dietetics and Home Economics, 18 (3), 116-119.

Values and lifestyles (2001). World Wide Web (http://www. furture.sri.com)

Visser, E.M. \& Du Preez, R. (1996). Profiling the mature female apparel shopper. Journal of Dietetics and Home Economics, 24 (1), 1-6.

Visser, E.M. \& Du Preez, R. (1998). Consumer behaviour of mature female apparel shoppers: a cultural perspective. In N.J. Miller \& M.A. Littrell (Eds.), International apparel consumer behavior. A collection of readings and course activities. (pp. 41-51). Iowa: Iowa State University.

Visser, E.M. \& Du Preez, R. (2001). Apparel shopping orientation: two decades of research. Journal of Family Ecology and Consumer Sciences, 28, pp. 72-81. www.up.ac.za/academic/ acadorgs/saafecs/vol29/visser.html 